DOI: https://doi.org/10.30525/978-9934-26-020-9-16

Alexey Svistunov

$P h D$ in Economics, Doctoral Student

Khmelnytsky National University

\title{
INNOVATIVE TECHNOLOGIES IN ANTI-CRISIS MANAGEMENT OF A MACHINE-BUILDING ENTERPRISE
}

\section{Summary}

The study considers the main tasks and functions of the crisis management system of the enterprise. The essence of modern enterprise management technologies and their relationship with management decisions are highlighted, the main directions of development of innovative technologies that can be used both in the system of general management of the enterprise and in the system of crisis management are highlighted. The role of technological renewal in the efficiency of machine - building enterprises is shown. The essence of the method of assessing the quality and efficiency of technological renewal of the machine-building enterprise is revealed. The indicators used in assessing the quality and efficiency of technological renewal of machine-building enterprises are systematized. Features of formation of policy of technological updating of the enterprises of machinebuilding branch are allocated. The importance of technological renewal of machine-building enterprises in the introduction of innovative technologies in the system of crisis management of the enterprise is shown.

\section{Вступ}

Складна економічна ситуація в переважній більшості країн світу, багато техногенних аварій та екологічних катастроф підтверджують висновки вчених і практиків, що причиною постійних зовнішніх загроз сьогоднішньому та прийдешнім поколінням $є$ неправильна діяльність людини протягом тривалого періоду часу. Глобалізація та інтеграція соціально-економічних процесів пов’язують між собою усіх учасників різними складними механізмами і умовами, за яких кризова ситуація в одній країні спричиняє негативні впливи в усьому світі. Тому невідкладною $\epsilon$ проблема залучення до спільних конкретних дій усіх держав, спрямованих на захист екосистеми всієї планети. У зв'язку із цим посилюється актуальність розроблення та запровадження інноваційних технологій за всіма напрямами діяльності людини, на кожному промисловому підприємстві. Це вимагає від менеджменту підприємства чіткого розуміння процесів, що протікають на даний момент на підприємстві, їх оцінки та прийняття обгрунтованих управлінських рішень. За таких умов важливим та необхідним етапом $\epsilon$ також моніторинг зміни показників оцінки технологічного оновлення на 
промисловому підприємстві для забезпечення вчасного реагування на зміни зовнішнього та внутрішнього середовища.

Ефективне управління технологічним розвитком підприємства передбачає вибір та застосування дієвих методів та інструментів, які забезпечуватимуть: послідовність виконання робіт, формування відповідних організаційних структур, у форматі яких відбувається технологічний розвиток підприємств кожної галузі; нормативно-правові перетворення, що покликані формувати єдину систему нормативних актів, які визначають права та обов'язки усіх учасників технологічного процесу; економічні перетворення, до компетенції яких належить регулювання економічних взаємовідносин між підприємствами та галузями у напрямі досягнення поставлених цілей у сфері технологічного розвитку підприємства; компенсацію витрат у процесі придбання технологій; фінансування технологічної діяльності.

\section{Розділ 1. Основні завдання та функції системи антикризового управління підприємством}

Система управління підприємством розглядається вченими як сукупність усіх підсистем (елементів, процесів, технологій), взасмозв'язків між ними, що забезпечують задане функціонування підприємства та його подальший розвиток. Оскільки на промисловому підприємстві управління здійснюється шляхом спрямування управлінського впливу у вигляді формування завдань до кожного структурного підрозділу та виконавця, то, відповідно, технологія управління поєднує систематизовані знання, ідеї, винаходи з наукою, технікою і виробництвом, які потребують оперативного впровадження. Тому основне призначення системи управління підприємством полягає у тому, щоб формувати впливи на керовану систему з метою досягнення запланованого стану певною соціально-економічною системою.

У зв'язку з тим, що національній системі народного господарства сьогодні притаманна турбулентність, слід відзначити особливі підходи і до антикризового управління підприємством: антикризове управління розглядається як складова частина загальної системи менеджменту підприємства; антикризове управління спрямовується на попередження кризової ситуації; основними складниками системи антикризового управління підприємством виступають предмет, завдання і цілі, процес, суб'єкт та об'єкт управління, принципи, функції та критерії оцінки ефективності; суб'єктами антикризового управління підприємством можуть виступати власник підприємства, комерційний директор, функціональні антикризові менеджери - співробітники підприємства [2].

Таким чином, на сучасному етапі розвитку суспільства антикризове управління спрямовується на раннє попередження розвитку криз (недопущення негативного впливу від складних кризових ситуацій) та на адаптацію системи управління до змін у зовнішньому середовищі 
підприємства, що сприятиме сталому розвитку. У зв'язку із цим виникає необхідність формування на підприємстві системи антикризового управління, яка повинна забезпечувати постійний моніторинг кризових явищ, здійснювати планування, організацію та реалізацію антикризових заходів із метою збереження початкових позитивних характеристик підприємства, а також відновлення його ефективного функціонування.

Реалізація управлінських завдань відбувається через прийняття управлінських рішень. Надзвичайно важливим $\epsilon$ висновок М.П. Войнаренка, що процес прийняття управлінського рішення $\epsilon$ сукупністю послідовних дій суб’єкта управління, що починається 3 моменту виникнення проблемної ситуації і завершується реалізацією певних заходів щодо усунення даної ситуації [1, с. 17]. Ефективність прийняття управлінських рішень залежить від упорядкованого взаємозв'язку складових елементів системи управління, а також від правильності організації прямих і зворотних інформаційних потоків, що визначають сутність технології управління на підприємстві (рис. 1).

Відповідно, технологія управління являе собою певну послідовність дій, що використовуються під час розроблення цілей підприємства, механізмів їх досягнення, а також комплекс взаємопов'язаних між собою методів обробки управлінської інформації з метою формування, прийняття та реалізації управлінських рішень. При цьому можна виділити два основних взаємопов'язаних напрями: вироблення цілей i стратегії розвитку підприємства; формування технології прийняття та реалізації управлінських рішень.

Виконання такої умови потребуе формалізації всіх ділянок управління, тому особливого значення в технології управління сьогодні набувають іiі технічні елементи, до яких належать оргтехніка, засоби зв'язку, програмно-технічні комплекси та ін., що дають змогу знизити трудомісткість управлінських робіт, терміни їх виконання, а також підвищити якість прийнятих рішень, оскільки використання оперативної і довготривалої пам'яті сучасної комп'ютерної техніки, нейронних мереж, цифрових технологій дає змогу розширити інтелектуальні можливості фахівців для вирішення управлінських проблем та обгрунтованого вибору оптимальних управлінських рішень. 


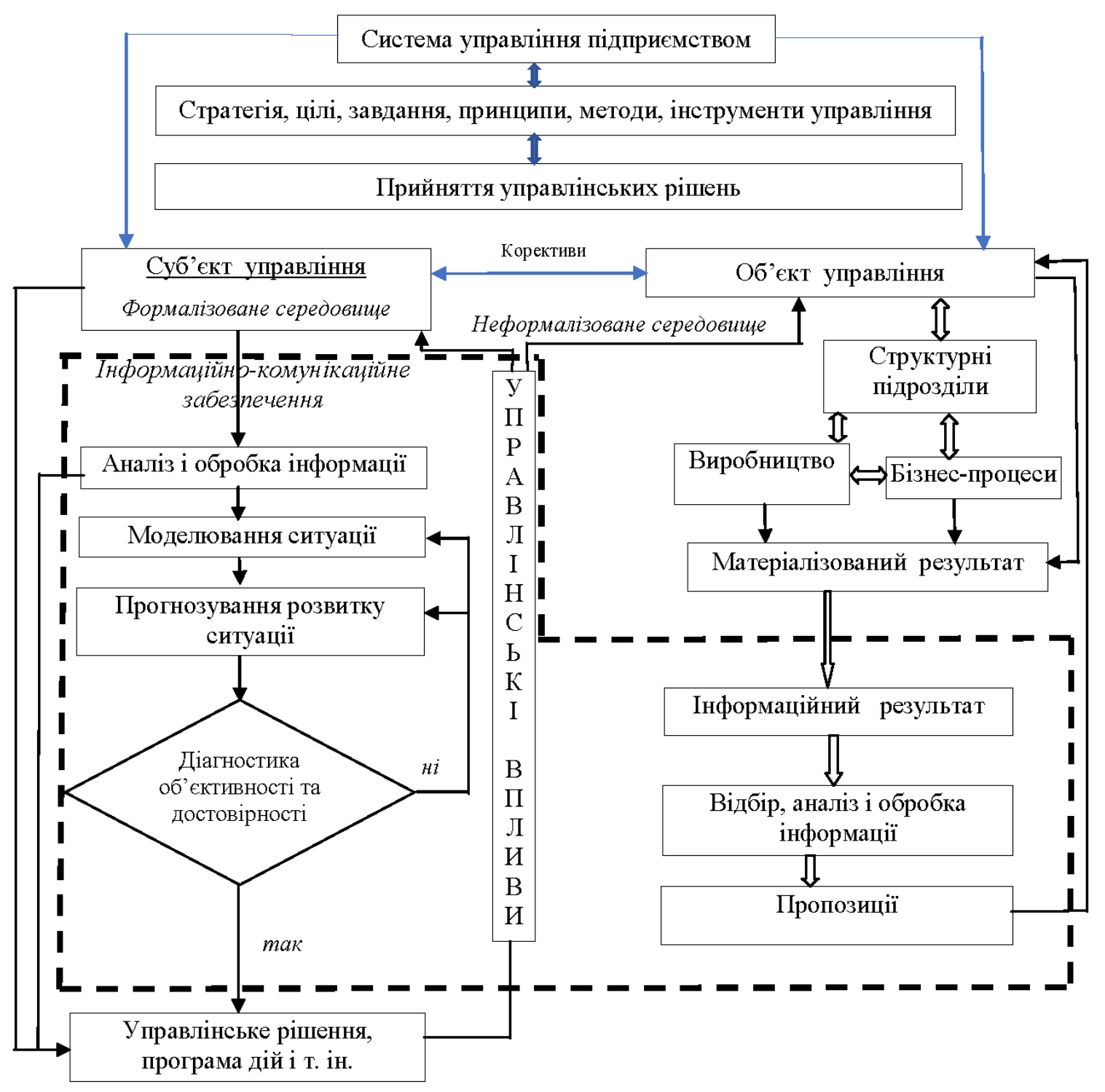

Джерело: побудовано автором за [1; 2; 7; 10; 15; 17]

\section{Розділ 2. Технологічне оновлення в системі управління підприсмством}

У широкому значенні сучасні зміни у трактуванні терміна «технологія» як економічної категорії полягають у тому, що іiї слід розглядати як процес, який цілеспрямовано здійснюється в різних сферах функціонування підприємства, охоплює взаємозв'язки між різними системами та компонентами 3 метою реалізації інноваційних підходів.

Ми поділяємо позицію вчених М.Г. Лобаса, В.В. Россохи, Д.О. Соколова, що технологія є сполучним механізмом між наукою, 
технікою і виробництвом, виступає процесом застосування накопичених досвіду та знань для ефективного здійснення з'єднання науки 3 виробництвом, а також складників виробництва між собою, без знання яких організація промислового виробництва на рівні останніх досягнень світової науки і техніки стає неможливою [8, с. 32-33]. Це підтверджується також і технологічними змінами, що відбувалися у суспільстві під впливом технологічних укладів i промислових революцій.

Отже, можемо зробити висновок, що гіпершвидкі темпи еволюції науково-технічного прогресу викликають глибокі перетворення як у сутності самих технологій, так і в технологізації всіх сфер діяльності людини. Тому сьогодні розуміння технології тісно переплітається 3 похідними, що відображують необхідність новацій, інноваційності, змін та оновлень в економіці для забезпечення сталого розвитку природи і суспільства.

Відповідно, фундаментом сучасних технологій виступають досягнення науково-технічного прогресу, а найбільш нові й прогресивні технології належать до високих технологій (англ. high technology, hightech), спроможних здійснити технологічний прорив у промисловості та застосовуються в наукомістких сферах: мікроелектроніці, робототехніці, обчислювальній техніці, літакобудуванні, атомній енергетиці, космічній техніці, мікробіологічній промисловості [11, с. 252].

Сьогодні промислові підприємства України поставлені перед викликами, пов'язаними 3 необхідністю становлення системного інноваційного розвитку з якісно новим економічним зростанням, що враховує екологічні потреби та ефективне інвестиційне забезпечення сучасних технологічних оновлень у всіх сферах життедіяльності людини. Зауважимо, що для технологічно спрямованих процесів, які відображуються термінами «технологічні зміни», «технологічний розвиток», «технологічні інновації», базовою категорією виступає термін «технологія», але всі вони є складниками об'ємної економічної категорії «технологічне оновлення». Ми також поділяємо думку науковців О.В. Шляги, Б.В. Масилюка, що між термінами «відновлення» та «оновлення» також існують відмінності: «відновлення» означає відтворення натурально-речової форми техніко-технологічної бази на попередній технічній основі, а «оновлення» - відтворення технікотехнологічної бази на новому технічному рівні шляхом упровадження технічних нововведень $[16$, с. 56]. Таку ж думку підтримує i Л.М. Шевчук, наголошуючи на тому, що оновлення - це зміна поколінь техніки, яка забезпечує перехід від традиційної техніки до принципово нової [14, с. 426]. I такий перехід, безумовно, супроводжується зростанням як доходів, так і витрат підприємства та підвищенням якості продукції і послуг (рис. 2). Г.Ю. Кучерук трактує технологічне оновлення як процес освоєння нових або вдосконалених засобів 
виробництва та технологій у цілому або зміни в організації виробничого процесу [7, с. 30]. В.Д. Боєв, Л.О. Шкварчук, М.В. Добрянська також наголошують на основних виробничих характеристиках технологічного оновлення і вважають, що воно стосується як механізмів реалізації виробничих процесів, так i їх організаційних аспектів [4, с. 20; 15 , c. $147-152]$.

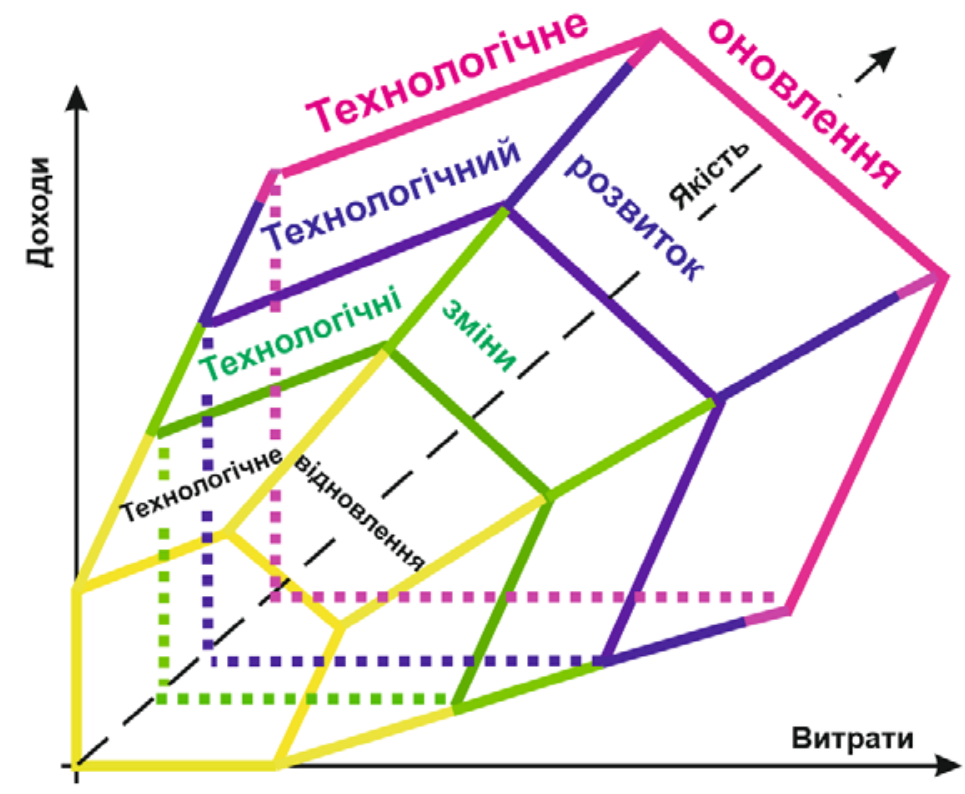

Рис. 2. Взаємозв' язок терміна «технологічне оновлення» та похідних категорій із доходами, витратами та якістю продукції і послуг

Джерело: побудовано автором за [14, с. 426; 15]

Авторами деталізуються виробничі елементи, які охоплюються технологічним оновленням: придбання засобів технологічного оснащення, яке доповнює виробниче обладнання для виконання певної частини технологічного процесу, втілення змін у них, а також технологічні зміни в процедурах, методах, стандартах виробництва та контролі якості, у пов'язаному із цим програмному забезпеченні, необхідному для виготовлення нового продукту або застосування нового технологічного процесу, впровадження нових послуг або методів їх виробництва чи їх удосконалення; пробне виробництво або випробовування, якщо передбачається доробка конструкції.

Як справедливо зазначає О.Я. Дмитрук, технологічне оновлення необхідне у зв'язку з об'єктивними потребами в розвитку прогресивних технологій для певного етапу науково-технічного прогресу i для підвищення конкурентоспроможності виробництва та виходу економіки країни із затяжної кризи і депресії [5, с. 97]. Технологічне оновлення розглядається автором як процес раціонального розширення виробництва на новій технічній основі, яке передбачає впровадження 
досягнень науково-технічного прогресу 3 максимально можливим використанням існуючого потенціалу підприємства, новітніх технологій та обладнання задля створення конкурентоспроможної інноваційної продукції та технологій виробництва [5, с. 100].

Узагальнення підходів учених щодо розуміння технологічного оновлення на сучасному етапі розвитку економіки дає змогу виділити характерні ознаки його сутнісного наповнення:

- технологічному оновленню властиві: динамізм - відображає виконання будь-яких процесів, рухів, дій, при цьому процеси можуть бути виробничими, фізіологічними, управлінськими, творчими; конкретність - відображає цілеспрямованість їі процесів до досягнення певного результату, таким чином, усі технології - штучні, тобто цілеспрямовано організовуються i контролюються людиною; матеріальна зумовленість - припускає наявність трьох компонентів об'єктивного світу: предметів праці, засобів праці й самої праці; логічність - виконання технології припускає проходження послідовності дій, операцій, рухів, тобто впорядкованих у часі й просторі основних, допоміжних і обслуговуючих процесів [2, с. 71; 13; 17];

- необхідність технологічного оновлення викликається зовнішніми i внутрішніми чинниками, які досліджуються менеджментом підприємства, i за результатами досліджень плануються заходи технологічного оновлення, спрямовані на забезпечення адаптивності підприємства, ефективного використання потенціалу;

- основні риси сучасного економічного розвитку розкривають концептуальні положення економіки, заснованої на знаннях, згідно 3 якими в технологічному оновленні знання набувають ключових позицій, визначають темпи, умови та успішність його здійснення;

- технологічне оновлення залежить від багатьох зовнішніх i внутрішніх чинників, проте його рушійною силою виступає науковотехнічний прогрес. Тому технологічне оновлення охоплює всі сфери функціонування підприємства для забезпечення реалізації передових досягнень науки i техніки, які вносять структурні зміни у функціонування підприємства, його бізнес-процеси та взаємодію із зовнішнім середовищем, що потребує безперервного оновлення на основі інноваційності, інтелектуалізації та ресурсного забезпечення;

- технологічне оновлення під впливом глибоких змін у техніці, технологіях, розвитку цифровізації всіх сфер життєдіяльності людини забезпечує не лише техніко-технологічне оновлення матеріальнотехнічних ресурсів, виробничих технологій, а й організаційної, управлінської систем, функціональних взаємозв'язків між підрозділами підприємства, всіх сфер його функціонування, включаючи взаємодію із зовнішнім середовищем, унаслідок чого підприємство переходить на якісно новий рівень розвитку. 
Отже, за результатами контент-аналізу можна сформулювати таке визначення технологічного оновлення: це система накопичення та трансформації знань із метою їх матеріалізації для втілення в засоби праці, способи виробництва, виробничо-господарські та організаційноуправлінські процеси, що охоплює всі сфери функціонування підприємства для забезпечення реалізації передових досягнень науки i техніки, гармонійного виробництва та сталого розвитку підприємства на довгострокову перспективу.

На підставі проведеного дослідження слід зробити висновок, що технологічне оновлення підприємства на системній основі сприятиме запровадженню інноваційних технологій як у загальну систему менеджменту підприємства, так і в систему антикризового управління.

\section{Розділ 3. Оцінка якості та ефективності технологічного оновлення підприсмств як елемент інформаційного забезпечення антикризового управління}

Технологічне оновлення $\epsilon$ запорукою успішного функціонування підприємств машинобудівної галузі, перед якими відкривається низка можливостей для досягнення ефективного розвитку та адекватного реагування на зміни зовнішнього і внутрішнього середовища. У зв’язку iз цим існує постійна необхідність у формуванні ефективної методики оцінки якості та ефективності технологічного оновлення на машинобудівних підприємствах, 3 огляду на складність та багатоаспектність дослідження окресленої проблематики.

Iз появою нових ризиків i загроз діяльності вітчизняних машинобудівних підприємств потребують подальшого вивчення питання забезпечення їх технологічного оновлення, що актуалізує необхідність виокремлення найбільш дієвої методики оцінки його якості та ефективності. Сьогодні в умовах невизначеності та нестабільності вітчизняної економіки досягнення збалансованості господарської діяльності машинобудівних підприємств, висока якість послуг, технологій і фінансових інструментів, а також здатність протистояти загрозам визначаються рівнем якості й ефективності технологічного оновлення промислового підприємства, яке формується низкою послідовних дій, що характеризуються наявністю об'єкта та суб'єктів його здійснення. Під час прийняття рішення щодо технологічного оновлення необхідно враховувати зміни всіх техніко-економічних характеристик об’єкта та проводити оновлення у два етапи 3 порівнянням якості та ефективності: придбання нового і подальшого використання старого обладнання; альтернативні варіанти оновлення.

Одним із варіантів оновлення $\epsilon$ підтримка технологічної бази: капітальний ремонт устаткування; технічне доозброєння підприємства; заміна спрацьованого устаткування новим; заміна окремих вузлів та деталей обладнання. До розвитку технологічної бази доцільно віднести 
такі варіанти технологічного оновлення: модернізацію, технічне переозброєння, реконструкцію, розширення, нове будівництво.

Якісне та ефективне технологічне оновлення на підприємстві вирішує такі завдання: постійне оновлення асортименту продукції; оновлення i створення нових виробничих систем; нарощування ефективності виробничо-збутової діяльності [6]. Перехід на технологічне оновлення сприяє: більш суттєвому підвищенню продуктивності праці та якості продукції, ніж удосконалення техніки за наявної технології, зниженню відходів виробництва і підвищенню функціонального використання сировини; економії на масштабах та ефективному використанню капітальних вкладень.

В успішному проведенні технологічного оновлення машинобудівних підприємств додаткові складнощі полягають в обмеженні фінансових ресурсів. Власні кошти підприємств $є$ найвагомішим джерелом фінансування цих процесів. Проте ці кошти $є$ недостатніми для ефективного процесу технологічного оновлення. Тоді у підприємства існує два варіанта: або пошук інвесторів, або звернення за банківськими кредитами. Кредиторська заборгованість присутня на багатьох підприємствах і часто є чи не єдиним джерелом залучення коштів. Якщо підприємство здійснює масштабне технологічне оновлення i залучає інвесторів до цього процесу, то вони можуть висунути певні вимоги. Якщо економічні переваги нових технологій перевищують переваги старих, за інших рівних умов упровадження нових технологій $\epsilon$ ефективним.

Із метою визначення доцільності технологічного оновлення підприємства необхідною $є$ оцінка всіх надходжень і витрат у разі експлуатації старого обладнання та придбання нового. Сутність даного способу полягає у забезпеченні прийняття рішення щодо заміни обладнання, яке використовується, новим. Із можливих варіантів придбання нового обладнання доцільно вибрати найкращий для певного виду виробництва.

Аналіз кожного 3 альтернативних варіантів оцінки якості та ефективності технологічного оновлення машинобудівного підприємства варто здійснювати за етапами проведення: попереднього аналізу - дає змогу орієнтовно оцінити прибуток від вибору варіанта оновлення; аналізу ринку - передбачає оцінку попиту і можливостей реалізації підприємством продукції, виготовленої після проведення оновлення; технічного аналізу - визначення різновидів техніки чи технології, оптимальних щодо цілей оновлення, з можливістю залучення експертів; фінансово-економічного аналізу - включає аналіз основних фінансовоекономічних показників за декілька попередніх років i поточний фінансовий стан підприємства, прогноз витрат i прибутку, оцінку ефективності оновлення. 
Під час проведення оцінювання якості й ефективності технологічного оновлення машинобудівного підприємства необхідно повністю обгрунтувати перспективи проєкту та визначити його ефективність.

Комплексна методика 3 оцінки якості та ефективності технологічного оновлення машинобудівного підприємства вимагає виконання таких кроків: виділення технологічного складника як домінуючого; визначення критеріїв, які дають змогу оцінити поточний стан даного складника; визначення рівня впливу критеріїв домінуючого складника на інші складники; розроблення методів розрахунку конкретних показників оцінки якості та ефективності технологічного оновлення і визначення їх нормативних значень; визначення джерел фінансування технологічного розвитку.

На основі опрацювання результатів досліджень щодо висвітлення методики технологічного оновлення підприємств $[5 ; 6 ; 9 ; 11]$ нами виокремлено показники, які доцільно використовувати для грунтовного та всебічного аналізу оцінки й ефективності технологічного оновлення підприємств машинобудівної галузі.

У табл. 1 систематизовано показники якості й ефективності технологічного оновлення машинобудівних підприємств за кожним напрямом оцінювання, що дає змогу дослідити динаміку показників, своєчасно виявити відхилення від плану та здійснити прогноз на майбутні періоди.

Моніторинг та корегування $\epsilon$ завершальними етапами процесу технологічного оновлення підприємств машинобудівної галузі, що дає змогу отримати дані про ефективність застосування показників оцінки якості та ефективності технологічного оновлення. Для якісного й ефективного проведення технологічного оновлення підприємств машинобудівної галузі необхідною $є$ своєчасна та достовірна оцінка показників його діагностики і динаміки змін. Слід зазначити, що оцінювання якості та ефективності технологічного оновлення підприємств задля досягнення певних стратегічних цілей $є$ комплексом систематичних взаємопов'язаних дій, а не одноразовим процесом.

Разом із тим оцінювання механізмів та обладнання як основи технологічного оновлення підприємства має відбуватися як у короткостроковій перспективі, так і в довгостроковій. Різноманіття чинників зовнішнього та внутрішнього середовища та методів впливу на них зумовлюють необхідність дотримання принципів системності та комплексності під час вибору механізмів технологічного оновлення, що дасть змогу отримати оптимальний результат від його впливу на машинобудівне підприємство. 


\section{Показники якості та ефективності технологічного оновлення машинобудівних підприємств}

\begin{tabular}{|l|l|}
\hline \multicolumn{1}{|c|}{ Метод оцінки } & \multicolumn{1}{c|}{ Показники } \\
\hline $\begin{array}{l}\text { Оцінювання якості та } \\
\text { показнинсті за допомогою техногічного } \\
\text { складника економічного } \\
\text { потенціалу підприємства }\end{array}$ & $\begin{array}{l}\text { Темп відновлення основних засобів підприємства; } \\
\text { ступінь зношування основних засобів } \\
\text { підприємства; коефіцієнт еластичності; } \\
\text { фондоозброєність; фондовіддача; реальний рівень } \\
\text { завантаження виробничих потужностей; частка } \\
\text { науково-дослідних і конструкторських робіт у } \\
\text { загальному обсязі робіт; продуктивність праці }\end{array}$ \\
\hline $\begin{array}{l}\text { Оцінювання якості та } \\
\text { ефективності технологічного } \\
\text { оновлення через вартість та } \\
\text { рівень технології }\end{array}$ & $\begin{array}{l}\text { Вартість технології виробництва; рівень технології } \\
\text { звітного року в грошовому еквіваленті }\end{array}$ \\
\hline $\begin{array}{l}\text { Оцінка технологічного } \\
\text { оновлення } \\
\text { високотехнологічного } \\
\text { підприємства }\end{array}$ & $\begin{array}{l}\text { Вартісна оцінка технологічного оновлення; віддача } \\
\text { активів технологічного оновлення підприємства; } \\
\text { вартість активів, що формують технологічний } \\
\text { потенціал підприємства; коефіцієнт стану активів } \\
\text { технологічного потенціалу; показник відносного } \\
\text { приросту (зниження) технологічного потенціалу } \\
\text { підприємства }\end{array}$ \\
\hline $\begin{array}{l}\text { Оцінка механізмів та } \\
\text { обладнання як основи } \\
\text { технологічного оновлення } \\
\text { підприємства }\end{array}$ & $\begin{array}{l}\text { Повна собівартість об'єкта; відновлювальна } \\
\text { вартість об’єкта оцінки; базова вартість об'єкта }\end{array}$ \\
\hline
\end{tabular}

Джерело: побудовано автором за [5; 6; 9; 11$]$

Своєю чергою, вибір стратегічних пріоритетів і вироблення ефективного механізму їх здійснення лежать в основі реалізації стратегії оновлення матеріально-технічної бази виробництва. Серед основних напрямів стратегії технологічного оновлення доцільно виділити: оцінку потреб технологічного оновлення підприємства, визначення ефективних ринкових ніш технологічного рівня, формування конкурентних переваг засобів виробництва; наявність вітчизняних наукових розробок, винаходів; рівень соціально-економічної ефективності технологій [5, с. 99].

Необхідність пошуку та обгрунтування методики оцінки якості i ефективності технологічного оновлення підприємств машинобудівної галузі зумовлена низкою причин технологічного, економічного та організаційного характеру. Одним із ключових чинників низьких конкурентних переваг підприємства $є$ застарілі технології, які обмежують випуск нової або з поліпшеними властивостями продукції. Активізація пошуку джерел фінансування в умовах низьких інвестиційних можливостей є вкрай важливою. При цьому необхідно забезпечити системний підхід до процесу управління та підвищення рівня кваліфікації робітників машинобудівного підприємства. 
Результатами технологічного оновлення $\epsilon$ випуск нової або значно вдосконаленої продукції, освоєння нових ринків збуту, підвищення конкурентних позицій та поліпшення фінансових результатів машинобудівного підприємства. Для машинобудівного підприємства політика технологічного оновлення повинна забезпечувати розвиток та зростання його конкурентоспроможності за рахунок використання новітніх технологій та досягнень у сфері техніки. Саме за рахунок постійного впровадження у виробництво нових, найсучасніших механізмів, техніки та технологій як зарубіжних, так і вітчизняних розробників, обгрунтованого скорочення витрат операційної та інших видів діяльності, підвищення якісних характеристик технологій має забезпечуватися ефективне функціонування виробничої системи [6]. Послідовність реалізації політики технологічного оновлення може здійснюватися поетапно.

Перший етап - виявлення цілей політики технологічного оновлення: формується мета та визначаються завдання політики технологічного оновлення машинобудівного підприємства, оцінюється його потенціал здійснення технологічного оновлення.

На основі дослідження загальних тенденцій техніко-технологічного розвитку ринку, моніторингу технологій, аналізу чинників зовнішнього середовища підприємства (економічних, техніко-технічних, політичних, соціальних) формуються цілі політики технологічного оновлення.

Основними цілями технологічного оновлення підприємства, які відповідають його місії, мають бути $[3 ; 5 ; 6]$ : прогнозування та швидка реакція підприємства на зміни потреб ринку, а також задоволення вимог споживачів; забезпечення конкурентоспроможності підприємства та потреб у технологіях; вибір способу технологічного оновлення, що має відповідати потребам підприємства та забезпечувати загальну стратегію розвитку; створення умов для постійного оновлення виробничої системи та впровадження передових технологій, забезпечення ефективного функціонування виробничої системи; надання підприємству додаткових ефектів на основі комерціалізації технологій, які максимально відповідають потребам споживача; зростання прибутків та ринкової вартості підприємства, отримання соціального ефекту завдяки технологічному оновленню; запобігання високому ступеню ризику, пов'язаного з технологічним оновленням на підприємстві.

Другий етап стратегічного аналізу - оцінюється ресурсний потенціал підприємства, проводиться аналіз ефективності використання основних засобів, виявлення «проблемних місць» підприємства. До цього етапу слід віднести здійснення технологічного аудиту, основним завданням якого $\epsilon$ аналіз поточного технологічного статусу підприємства, визначення сильних та слабких позицій його технологічних активів, оцінювання ефективності технологічного оновлення як засобу досягнення конкурентних переваг та стратегічних цілей підприємства. 
Будучи важливим інструментом досягнення технологічного розвитку підприємства, технологічний аудит сприяє процесам систематизованої обробки знань та перетворення їх на технологічні активи [5].

Третій етап - формування політики технологічного оновлення підприємства: розроблення, аналіз та оцінка альтернатив, а також вибір і обгрунтування способу реалізації політики технологічного оновлення підприємства, якому надається перевага.

Основною метою етапу визначення типу політики технологічного оновлення підприємства $\epsilon$ розроблення оптимальних способів отримання та експлуатації технологій підприємства, зорієнтованих на зростання, заміщення чи реалізацію існуючих технологічних активів у контексті ефективного функціонування виробничої системи [12].

Четвертий етап реалізації технологічного оновлення підприємства передбачає формування портфеля інноваційних технологій, в основі якого покладено розрахунок економічної доцільності варіантів технологічного оновлення.

На п’ятому етапі здійснюється контроль реалізації програми технологічного оновлення підприємства, іiі коригування: визначення конкурентних переваг у майбутньому, що мають технологічну спрямованість, прогнозування майбутніх напрямів технологічного розвитку, оцінка реалізації політики технологічного оновлення підприємства, аналіз цільових індикаторів політики технологічного оновлення підприємства.

Відповідно до запропонованої послідовності, процес вибору та реалізації політики технологічного оновлення машинобудівних підприємств в ефективному функціонуванні виробничої системи повинен відповідати таким вимогам [3; 9]: давати змогу не лише проаналізувати дієвість технологічного оновлення, а й виявити можливості та резерви зростання продуктивності, визначити ефективність функціонування виробничої системи; включати показники, що характеризують політику технологічного оновлення за всіма складниками; забезпечувати можливість порівняння показників, які використовуються для аналізу на різних підприємствах; спрямовувати на виконання підприємством поточних та перспективних завдань, узгоджувати процес їх виконання з існуючою на підприємстві звітністю; мінімізувати витрати на збір та обробку інформації згідно з вибраною системою показників; визначити складники політики технологічного оновлення для розроблення подальшої стратегії розвитку підприємства.

\section{Висновки}

Відповідно до отриманих результатів, слід зробити висновок, що запровадження інноваційних технологій у систему антикризового управління машинобудівним підприємством можливе на основі здійснення технологічного оновлення. Важливим та необхідним етапом 
також $є$ моніторинг зміни показників оцінки технологічного оновлення на машинобудівному підприємстві для забезпечення вчасного реагування на зміни зовнішнього та внутрішнього середовища. Реалізація політики технологічного оновлення машинобудівних підприємств вз метою забезпечення ефективного функціонування виробничої системи визначається сукупністю його складників та містить низку економічних показників, які характеризують можливості підприємства в освоєнні нових чи вдосконалених технологій під час виробництва продукції. Обгрунтовуючи вибір політики технологічного оновлення машинобудівних підприємств, необхідно враховувати ii відповідність загальній стратегії розвитку підприємства, прийнятність за рівнем ризику, передбачати готовність ринку до сприйняття оновленої продукції. Здійснення технологічного оновлення потребує значних фінансових ресурсів, оскільки визначається збільшенням поточних витрат i зниженням рентабельності виробництва. Своєю чергою, реалізація економічних переваг нових технологій, які відображаються у зростанні прибутку підприємства, дає змогу компенсувати витрати на освоєння, забезпечити протистояння кризовим явищам та сталий розвиток підприємства.

Сучасні управлінські технології в системі антикризового управління можуть бути реалізовані лише на основі сучасних інформаційних технологій. Автоматизація управлінського процесу, доступне програмне забезпечення, яке постійно оновлюється, глобальні інформаційні мережі, цифрові технології докорінно змінюють усі ланки виробничогосподарської діяльності підприємства - від виробництва до споживання, а також його організаційно-управлінську систему, що потребує проведення подальших досліджень.

Нині все більшого значення для вітчизняних підприємств набувають нові інформаційні технології і системи комплексного характеру, які допомагають у вирішенні проблем - від підготовки виробництва до збуту продукції та забезпечують інтеграцію функцій управління.

\section{Список використаних джерел:}

1. Войнаренко М.П. Управління матеріально-технічним забезпеченням (менеджмент постачально-збутових процесів) : навчальний посібник. Хмельницький : ЗДУ, 2003. $111 \mathrm{c.}$

2. Войнаренко М.П., Смчук Л.В. Інформаційні системи як основа розвитку технологій управління. Бізнес Інформ. 2012. № 10. С. 70-73.

3. Біла Г.І., Хома І.Б. Технологічне оновлення машинобудування на інноваційній основі. Управління інновачійним прочесом в Украӥні: проблеми, перспективи, ризики : зб. матер. III Міжнародної науково-практичної конференції. Львів : Львівська політехніка, 2010. С. 39-41.

4. Боев В.Д. Имитационное моделирование систем. Москва : Юрайт, 2017. 253 с.

5. Дмитрук. О.Я. Технічне оновлення як складова розширеного відтворення підприємств машинобудівного комплексу в умовах інтеграції. Вісник Хмельнииького наиіонального університету. Економічні науки. 2010. № 2. Т. 1. С. 97-100. 
6. Кисловська Є.Л. Управління техніко-технологічною базою підприємства Вісник КHEУ. URL: https://kneu.edu.ua/userfiles/ conf_26290314/6/Kislovska.doc

7. Ковальчук I.B. Економіка підприємства. Система показників оцінки ефективності діяльності підприємства на основі традиційного підходу. URL: $\quad$ http://westudents.com.ua/glavy/15452-sistema-pokaznikv-otsnki-efektivnostdyalnost-pdprimstva-naosnov-traditsynogo-pdhodu.html

8. Кучерук Г.Ю. Напрямки технологічного оновлення промислових підприємств. Економіка. Менеджмент. Бізнес. 2016. № 1. С. 28-34.

9. Лобас М.Г., Россоха В.В., Соколов Д.О. Управління інноваційнотехнологічним розвитком агросфери : монографія / за ред. М.Г. Лобаса. Київ : ННЦ «IAE», 2016. $416 \mathrm{c}$.

10. Маслак О.I., Маслак М.В., Безручко О.О. Фактори розвитку трансферу технологій машинобудівного підприємства. Актуальні проблеми економіки. 2016. № 5. C. 171-181.

11. Бобровська О.Ю., Савостенко Т.О., Польська І.Е. Методологічні основи формування системи інформаційно-аналітичного забезпечення антикризового управління територіальним розвитком : наукова розробка / за заг. ред. О.Ю. Бобровської. Київ : НАДУ, 2012. 56 с.

12. Хома І.Б. Теоретичні аспекти формування структури технологічного оновлення машинобудівних підприємств. Економічний простір. 2015. № 98. С. 249-262.

13. Хохлов М.П., Баликов С.В. Визначення показників для оцінки ефективності діяльності підприємства. URL: http://www.rusnauka.com/12_KPSN_2010/Economics/ 63130.doc.htm

14. Чмутова I.M. Сутність технології управління та іï ключові ознаки. Науковий вісник Чернівецького університету. Серія «Економіка». 2014. Вип. 710-711. С. 70-75.

15. Шевчук Л.М. Оновлення техніко-технологічної бази вітчизняних підприємств: основні елементи управління. Збірник наукових працуь Подільського державного аграрно-технічного університету. 2011. Вип. 19. С. 425-429.

16. Шкварчук Л.О., Добрянська М.В. Інвестиційне забезпечення технологічного оновлення підприємств: сутність і види. Вісник Дніпропетровського університету. Серія «Економіка». 2013. Т. 21. Вип. 7(3). С. 147-153.

17. Шляга О.В., Масилюк Б.В. Управління оновленням техніко-технологічної бази промислового підприємства. Вісник Дніпропетровського університету. Серія «Економіка». 2014. Т. 22. Вип. 8(3). С. 55-60.

18. Yavas U. The efficacy of U. S. business education in the transfer of management technology - the case of Saudi Arabia. Journal of Education for Business. 1998. Vol. 74. № 1. P. 50-53.

\section{References:}

1. Voinarenko M.P. (2003) Upravlinnia materialno-tekhnichnym zabezpechenniam (menedzhment postachalno-zbutovykh protsesiv): navch. posib. Khmelnytskyi: ZDU, p. 111

2. Voinarenko M.P., Yemchuk L.V. (2012) Informatsiini systemy yak osnova rozvytku tekhnolohii upravlinnia. Biznes Inform, no.10, pp.70-73.

3. Bila H.I., Khoma I.B. (2010) Tekhnolohichne onovlennia mashynobuduvannia na innovatsiinii osnovi. Upravlinnia innovatsiinym protsesom $\mathrm{v}$ Ukraini: problemy, perspektyvy, ryzyky: zb. mater. III Mizhnarodnoi naukovo-praktychnoi konferentsii. Lviv: Vydavnytstvo Natsionalnoho universytetu «Lvivska politekhnika», pp. 39-41.

4. Boev V.D. (2017) Ymytatsyonnoe modelyrovanye system [System simulation]. Moscow: Yzdatelstvo Yurait. (in Russian) 
5. Dmytruk. O.I. (2010) Tekhnichne onovlennia yak skladova rozshyrenoho vidtvorennia pidpryiemstv mashynobudivnoho kompleksu v umovakh intehratsii. Visnyk Khmelnytskoho natsionalnoho universytetu. Ekonomichni nauky, no. 2, t. 1, pp. 97-100.

6. Kyslovska Ye.L. Upravlinnia tekhniko-tekhnolohichnoiu bazoiu pidpryiemstva. Visnyk KNEU. URL: https://kneu.edu.ua/userfiles/conf_26290314/6/Kislovska.doc

7. Kovalchuk I.V. Ekonomika pidpryiemstva. Systema pokaznykiv otsinky efektyvnosti diialnosti pidpryiemstva na osnovi tradytsiinoho pidkhodu. URL: http://westudents.com.ua/glavy/15452-sistema-pokaznikv-otsnki-efektivnost-dyalnostpdprimstva-naosnov-traditsynogo-pdhodu.html

8. Kucheruk H.Yu. (2016) Napriamky tekhnolohichnoho onovlennia promyslovykh pidpryiemstv. Ekonomika. Menedzhment. Biznes, no. 1, pp. 28-34.

9. Lobas M.H., Rossokha V.V., Sokolov D.O. (2016) Upravlinnia innovatsiinotekhnolohichnym rozvytkom ahrosfery: monohrafiia / za red. M.H. Lobasa. Kyiv: NNTs «1AE», p. 416.

10. Maslak O.I., Maslak M.V., Bezruchko O.O. (2016) Faktory rozvytku transferu tekhnolohii mashynobudivnoho pidpryiemstva. Aktualni problemy ekonomiky, no. 5, pp. 171-181.

11. Bobrovska O.Y., Savostenko T.O., Polska I.E. (2012) Metodolohichni osnovy formuvannia systemy informatsiino-analitychnoho zabezpechennia antykryzovoho upravlinnia terytorialnym rozvytkom : nauk. rozrobka / za zah. red. O.Yu. Bobrovskoi. Kyiv: NADU, p. 56.

12. Khoma I.B. (2015) Teoretychni aspekty formuvannia struktury tekhnolohichnoho onovlennia mashynobudivnykh pidpryiemstv. Ekonomichnyi prostir, no. 98, pp. 249-262.

13. Khokhlov M.P., Balykov S.V. Vyznachennia pokaznykiv dlia otsinky efektyvnosti diialnosti pidpryiemstva. URL: http://www.rusnauka.com/12_KPSN_2010/Economics/ 63130.doc.htm

14. Chmutova I.M. (2014) Sutnist tekhnolohii upravlinnia ta yii kliuchovi oznaky. Naukovyi visnyk Chernivetskoho universytetu : zb. nauk. prats. Seriia «Ekonomika». Chernivtsi: ChNU, vol. 710-711, pp. 70-75.

15. Shevchuk L.M. (2011) Onovlennia tekhniko-tekhnolohichnoi bazy vitchyznianykh pidpryiemstv: osnovni elementy upravlinnia. Zbirnyk naukovykh prats Podilskoho derzhavnoho ahrarno-tekhnichnoho universytetu, vol. 19, pp. 425-429.

16. Shkvarchuk L.O., Dobrianska M.V. (2013) Investytsiine zabezpechennia tekhnolohichnoho onovlennia pidpryiemstv: sutnist i vydy. Visnyk Dnipropetrovskoho universytetu. Seriia: Ekonomika, t. 21, vol. 7(3), pp. 147-153.

17. Shliaha O.V., Masyliuk B.V. (2014) Upravlinnia onovlenniam tekhnikotekhnolohichnoi bazy promyslovoho pidpryiemstva. Visnyk Dnipropetrovskoho universytetu. Seriia: Ekonomika, t. 22, vol. 8(3), pp. 55-60.

18. Yavas U. (1998) The efficacy of U. S. business education in the transfer of management technology - the case of Saudi Arabia. Journal of Education for Business, vol. 74, no. 1, pp. 50-53. 